\title{
Technological Changes and Manufacturing Unions in South Africa: Failure to Formulate a Robust Response
}

\author{
Mondli Hlatshwayo, University of Johannesburg, South Africa
}

\begin{abstract}
Technological innovation has had far-reaching implications for labour and for the world of work generally. It has led to job losses, the creation of new jobs, the loss of some skilled positions and the creation of new ones, and an increase in the quality of products like steel. Literature that addresses union responses to technological innovation in production has tended to classify them as either reactive or proactive, with reactive responses predominating. This article examines how South African trade unions in the steel, automotive and chemical industries have responded to technological changes. Based on interviews and documentary analysis, it argues that the unions have adopted a rearguard approach, responding to technological changes only after management has already implemented them. Unions have tended to prioritise "politics from above" and traditional union issues such as wage negotiations. In addition, the current division within unions has contributed to their inability to improve their servicing of members, let alone organise precarious workers and engage with issues of technological innovation.
\end{abstract}

\section{KEY WORDS}

Manufacturing; Unions; Technology; Rearguard action; Collective bargaining

\section{Introduction}

At the 2016 World Economic Forum in Davos, governments and world business leaders discussed the "Fourth Industrial Revolution". The IndustriALL Global Union, the biggest international trade union federation of manufacturing and mining workers in the world, intervened in the discussion, stating, "Technological changes in the workplace have deep social implications, as temporary and casual work risks to spread further, unemployment runs high, wages are low and workers' rights attacked" (IndustriaAll, 2016: 1).

An increase in the use of technology and related capital intensity has had important consequences for the labour process and for the position of workers. Technological changes in production processes tend to lead to the intensification of work, the restructuring of skills and the creation of a group of skilled workers that comprises a tiny minority of the total workforce. Management is involved in the planning and monitoring of work, while the vast majority of workers' lives are regulated by machines and computers; in many instances, workers have actually been displaced by machines. In the context of technical changes, trade unions, as representatives of workers, have generally struggled to defend the jobs of their members (Sandberg, 1985; Saiyadain, 2001; Danford et al., 2004). 
This article argues that trade unions in South Africa's manufacturing sector have not conceptualised technologies of production as a contested terrain that requires research, education and organisational capacities in order to respond comprehensively to automation initiated by management. Instead, the unions have fought what can be compared to a defensive action carried out by a retreating army. Union leadership has tended to focus on the politics of "upward social mobility" or securing top positions in government and state companies for individual leaders. The current weaknesses of trade unions and the divisions within their ranks make it impossible to envisage unions that are able to defend the interests of workers while also responding comprehensively to automation.

Several factors have led to the failure of South African manufacturing unions to view technology as a contested terrain. Wages and working conditions largely defined collective bargaining, and this had a lot to do with unions trying to subvert the cheap labour system which characterised industrial relations in South Africa. Unlike countries like Germany, there were no institutionalised forums such as works councils, so labour and employers were compelled to negotiate technological changes. In the absence of institutionalised bargaining over technology and production, the manufacturing unions narrowly defined collective bargaining in the terrain of wages, to the exclusion of technology and production issues. On the other hand, employers tended to use ad hoc workplace-based meetings to gain support for retrenchments among union leaders and shop stewards, causing a collapse in participation as union members resisted retrenchments and job losses.

\section{Trade Union Responses to Technological Changes}

The literature on trade union responses to technological changes divided them into two broad strands, namely unions that viewed technological innovation as a contested terrain and those that adopted a rearguard reaction after management had introduced new technology.

Streeck and Thelen (2005) write about the evolution of co-determination and the emergence of the works councils in the German system of industrials relations:

At its inception, co-determination was partly intended as an independent, workplace-based counterweight to Germany's rather radical national labor movement ... By the 1950s, however, works councils had been fully though not formally incorporated into the strategies of, now moderate, trade unions. Now, not only did co-determination not detract from the strength of the unions, but it magnified their voice by providing them with a stable, legally anchored foothold in workplaces across the entire economy (Streeck and Thelen, 2005: 18).

According to Thelen (1991), the introduction of new technology and the subsequent retrenchments disturbed "the industrial peace", which was characterised by unions not treating technology as a contested terrain. In 1978, workers in the Nord Württemberg/Nord Baden region of the union Industriegewerkschaft Metall (IG Metall) came out on strike because management introduced new technology and precarious forms of work. These developments compelled IG Metall to view technology as a contested terrain; this meant that the union had to use the works councils to challenge technological changes, build its research capacity and use its membership to bargain for better deals on technology.

Konrad Siegel advises the National Union of Metalworkers of South Africa (NUMSA), which is

the biggest metalworkers' union in the country, on workplace restructuring and technological 
innovation. He is a member of IG Metall and he was a shop steward and a member of the works council in a factory in Germany which manufactured agricultural machines. In the 1980s, the firm was about to close because it was faced with strong competition. Siegel used the works council to authorise the formation of work teams which redesigned the plant and the machines. The plan had the blessing of IG Metall's membership and its leadership. Treating the workplace and technology as a terrain of struggle led to a productivity increase of 40 per cent and the avoidance of job losses (Hlatshwayo, 2014).

However, treating technology as a contested terrain is not a panacea, and German unions do in fact face workplace challenges such as retrenchments and precarious work (Dribbusch, 2013; Markovits, 2016)). In spite of this, it must be conceded that German unions like IG Metall have used the legislative frameworks of the works councils, research and membership support to devise concrete proposals for mitigating the negative effects of technological change, such as job losses (Mashilo, 2010; Masondo, 2010; Hlatshwayo, 2014).

Based on his Australian experiences, Mathews (1989) advised trade unions that they would have to define their own programmes of work reorganisation and technical innovation, since focusing on wage issues without strategising only around production could hurt trade unions and their members if it led to management being able to change production without any substantial reactions from the unions.

The literature that views trade union responses as mainly reactive also tends to argue that trade unions view production or technological innovation mainly as the preserve of management, while wages, issues of disciplinary process and victimisation by employers are seen as the main concerns of the unions. This is because workers join unions in the hope that they will bargain for better wages and improved working conditions (Bamber, 1988; Bacon, Blyton and Morris, 1996). The result of not engaging with technology is that unions are "caught on the back foot" when new technology is introduced (Hlatshwayo, 2014: 203). Trade unions that adopted a rearguard approach tended to bargain over the effects of technological change only after automation had been introduced, leaving little room to manoeuvre and an inability to protect some jobs, which is the primary purpose of a union (Bamber, 1988; McLoughlin and Clark, 1988; Bacon et al., 1996).

American, British, African and Asian trade unions tend to adopt a rearguard approach to technological changes (Bamber, 1988; Bacon et al., 1996; Saiyidan, 2001; Lukman, 2012;), unlike their German, Scandinavian and, in some cases, Australian counterparts. But what accounts for the different approaches to technological changes? The German unions, for instance, inherited works councils as products of struggle, and they were able to use these councils to influence production. As in some cases in Australia, trade unions that view technology as a contested terrain tend to build their research capacity with the sole objective of formulating proposals that respond to management's strategies regarding production. Another rider is that management must be willing to engage meaningfully with the trade unions.

With a very few exceptions (Maree, 1984; Hlatshwayo, 2014), South African scholarship on trade union responses to technological innovation is extremely thin. Labour process studies tend to focus on general work reorganisation, including plant layout, skills training and deployment, technology, labour supply and working conditions (Jarvis et al., 1999; Von Holdt, 2003; Masondo, 2010; Mashilo, 2010). While not trying to reduce all workplace changes to issues of technology, studying technological innovation as a specific area is important because of the rapid technological changes taking place in many workplaces (Bonin, 2013). 
An examination of technology and its impact on work in the textile industry was conducted by Bonin (2013). The specific area on trade union responses to technical changes was later investigated by the author (Hlatshwayo, 2014) who focused on union responses in the very specific context of the ArcelorMittal Vanderbijlpark plant. The research reflected on complaints raised by trade unions regarding consultations when new technology was introduced. The conclusion was reached that NUMSA and Solidarity, which both organised workers at the plant, adopted a reactive or rearguard approach to automation, and that this had a negative effect on employment.

This research extends the scope of the work done before 2012; it examines technological changes in the context of the manufacturing sector, which in this instance includes the steel, automobile and chemical sub-sectors. The first study was conducted before 2012 (Hlatshwayo, 2014), when NUMSA was still part of the Congress of South African Trade Unions (COSATU); however, this research was carried out when trade unions had been further weakened and there was an acceleration in the use of new technologies such as robotics. The implications of these divisions, and of weakened labour, could indicate that trade unions are currently unlikely to mount a formidable response to pervasive automation.

\section{Methodological Questions}

Most of the data for this paper was collected between 2016 and 2017 in the province of Gauteng, South Africa, which has a high concentration of manufacturing industries. Since the aim of the study was to understand how trade unions in South Africa's manufacturing sector have responded to technological changes, the approach adopted for the research had to be qualitative. The researcher was looking for reflections, insights and opinions on trade unions' responses to technological changes. This is an area that has been under-researched in the South African context, so it was necessary for the research to be exploratory. Boyce and Neale (2006: 3) advise that "in-depth interviewing is a qualitative research technique that involves conducting intensive individual interviews with a small number of respondents to explore their perspectives on a particular idea, program, or situation".

Three research methods were used for data collection, namely in-depth interviews, field notes, and documents from the unions and the Internet.

First, twenty in-depth interviews were conducted with union members, shop stewards, union organisers, a labour researcher, a staff member of an education non-governmental organisation (NGO) supporting trade unions, the manager of a nuts and bolts company and a quality consultant. Since this was a qualitative study, it required responses from individuals involved in and affected by technical change. A purposive sample was used: this meant that interviewees were selected for their knowledge of production processes and the role of technology (Palys, 2008). The interviewees were invited to narrate the histories of their working lives, to describe their jobs and to reflect on technological changes, the impact of technology on work, and worker and union responses to it. The interviews took between one and two hours each; they were conducted in English and were transcribed individually. In some instances, pseudonyms have been used in this article to protect workers and shop stewards from possible victimisation.

In-depth interviews are an invaluable source of data as they provide informants with spaces to give extra information about a topic, but they should be supplemented with data from other sources to ensure that the research is rigorous (Babbie et al., 2001). In this instance, newspaper articles and union documents were sourced from the Internet and used to bring diverse voices into the research. 
Finally, the researcher presented the findings to a shop steward council meeting organised by NUMSA on 18 February 2017. The discussion and the presentations were captured in the minutes of that meeting (Hlatshwayo, 2017a). Another presentation of the same document was delivered at the NUMSA head office on 8 March 2017 (Hlatshwayo, 2017b). The meeting was attended by sector bargaining co-ordinators, a national educator, a representative from the union's secretariat and a coordinator of the union's collective bargaining team. A proposal was made about how to respond to technological change in the future. The discussions that ensued were captured in the field notes and give details of the presentations, the reactions to the presentations and the recommendations made by participants (Taylor, Bogdan and DeVault, 2015).

Thematic coding is the analytical method generally used in qualitative research. It involves reading each transcript and document and identifying patterns relating to a research question (Braun and Clarke, 2006). The main question to be answered was: how have trade unions in the manufacturing sector responded to technological changes in the South Africa context? The first requirement was to understand the nature and form of technological changes in the manufacturing sector. The second objective was to develop an understanding of how trade unions have responded to automation. The coding was done manually, highlighting key words and phrases in documents and transcripts.

\section{Technological Changes}

Technological changes in a production process are wide-ranging, and discussion of aspects of automaton that emerged from the data are included here as they relate directly to workers. Below, the article critically discusses robotics, computerisation, changes in packaging and the role of technology in quality management.

First, there have been a number of changes in the production process, of which the introduction of robotics has been the most serious, in the sense that robots with bodies structured like those of human beings have taken over work that was previously done by human beings, eliminating the margin of error in production and being able to work day and night without breaks.

Research conducted by Citi and Oxford University suggested that 66.7 per cent of jobs could be performed by robots (Staff Writer, 2016). Addressing the tenth national congress of the biggest manufacturing union in South Africa, NUMSA, the Minister of Economic Development, Ibrahim Patel, warned that the "fourth industrial revolution" would be characterised by the use of robotics and that this would have a negative impact on jobs (Naki, 2016).

According to Venter (2016: 1), "Volkswagen Group South Africa (VWSA) recently installed 320 new robots at its body shop as the manufacturer ramps up to produce the new Polo - and one or two other unconfirmed models - at its Uitenhage plant in the Eastern Cape". As part of "revolutionising" production, the new robotics and other changes will also enable the plant to assemble other models like Audi and Skoda, thus saving on productions costs. The company argued that the introduction of a new assembly line dominated by robots would increase volumes of products and improve health and safety at the plant.

Second, John Appolis, who has organised workers in the chemical and paper industry, reflected on the use of computers and machines in these industries since the 1980s:

The main change in technology is the computerisation in the production process where certain functions of the process are taken over by computers, in a sense that computers direct the 
machines independently in the absence of workers where workers are reduced to pressing certain buttons, making certain observations and judgements in some of the settings, and monitoring readings (Appolis, Interview, 2017).

Second, some companies have used new machinery to "revolutionise" packaging to save costs. For example, June Nyathi, a quality consultant, spoke about his experiences between 2007 and 2008, when he worked as a technician in a plant which manufactured soap:

Yes. There were changes in technology. Various soaps are now packed in plastic packing. That's the major change that has happened in packaging because soap used to be packed in cardboard cartons. This was introduced to cut costs in packaging because with plastics there is less manpower required [in the production process] (Nyathi, Interview, 2017).

Third, technology is currently used not just to speed up the production process, but also to play a major role in quality management and control. Mblozi Hangwayo, a manager at a nuts and bolts plant, described the role of technology at the plant. He said, "A sorting machine with a camera has now been purchased" (Hangwayo, Interview, 2017). According to this informant, the machine uses a camera device to separate good-quality nuts and bolts from those with defects, taking over work which was previously done manually. Reflecting on the automation of quality control at the plant, Nyathi said,

Before, we used to test it [a sample] manually by titration method where we pour the solution in a test tube. We titrate manually and look out for the changing colour on the solution, but now with technology you just put the sample on the machine and select the reading (Nyathi, Interview, 2017).

\section{The Impact of Technical Change}

One of the major results of technological innovation has been job losses. Hangwayo commented:

The sorting process [in the nuts and bolts factory] had to be attended by fifteen to twenty people and we had to tell all those people that we didn't have jobs for them any more. We had introduced a computerised sorting machine which was fast, accurate, and efficient (Hangwayo, Interview, 2017).

Appolis also commented:

There has been a decrease [in workers]. If we take an explosives company and a paper company [for example], there has been dramatic declining in jobs. The explosives company has recently retrenched thousands of workers in a space of twenty years. You can see the scale of job losses in that particular company (Appolis, Interview, 2017).

Another effect of technology on work is an increase in the intensity of work and the need for workers to multi-task. Since the introduction of new technology and the subsequent reduction of workers, the remaining workers are required to perform more tasks. Commenting on the impact of technological 
changes and work reorganisation in a steel plant in the south of Gauteng, Mazedi Majafi, a metal worker, commented:

In the early 1990s in my plant, at first the company had manpower of about 25000 people and as I am talking now we are less than 5 000. So people were replaced with machines. The work that was done maybe by five people, you will find that it is done by one person and it's operated from the control box. So that person is basically doing everything by themselves (Majafi, Interview, 2017).

Majafi, a process controller in a steel plant, currently has no specific job. He does a lot of multi-tasking, including working in a laboratory and a control room; he also operates cranes and forklifts. The fact that work is dictated by the machines means that a worker has less control over the labour process, and because many tasks are performed by one worker, the intensity of work has been increased. Majafi elaborated:

Before, there were a lot of people, and people use to share work. Now one person is no longer performing one task. Now you do one thing; when you are done, you go and perform another task as the process goes on. You don't just stick to one position and do one specific job (Majafi, Interview, 2017).

Nyathi also commented on the contradictions in the reconfiguration of skills when new technology is introduced:

Previously, when things were done manually, you had to understand exactly what it is you are doing. Now with the new technology even if you get the results, you do not have an understanding of how the result came about. That has to do with the fact that they are coming from a machine. When you do things yourself, you understand the importance of why a certain step should be done. But the only disadvantage is that the manual process has a greater chance of having human errors. On the other hand, a computerised system has an advantage of being accurate. It is like a calculator (Nyathi, Interview, 2017).

In this instance, a quality technician's skills are appropriated by a machine which, of course, is accurate in measuring quality.

Malufi Kudwana, a worker employed at a steel processing plant, stated that new technology promoted health and safety in the production process:

I can say having the machine have made things a lot simpler because the machine is the one pulling the wire and it involves heat and stuff, and I think if it was people who were doing the job, a lot of them would get injured (Kudwana, Interview, 2017).

Similarly, Rob Rees, a labour researcher, argued that technology "that cuts out bad and dangerous work is a good thing" (Rees, Interview, 2017). However, Rees goes on to say that the problem is that the introduction of new technology is not driven by the desire to improve the working conditions of employees, but to increase company profits. 
Appolis argued that technology also led to the deskilling of workers:

Clearly it [technological change] has led to a process of deskilling. Instead of workers doing the work, developing and enhancing their knowledge of the skill, it's now done by the machine itself, and workers are just monitors and operate certain processes there. The workers' task then becomes very narrow, boring and specific because they basically have to monitor what's in front of them. It's just a matter of putting the settings right and the machine does the rest (Appolis, Interview, 2017).

Having examined the impact of technology on work, the question is: how have trade unions responded to automation?

\section{Consultation}

When Volkswagen (VW) introduced more than 320 robots at its plant near Port Elizabeth in October 2016 (Venter, 2016), NUMSA did not issue a statement commenting on the robotics, probably because it was caught off-guard. It subsequently emerged that the union was still formulating a response. There was a strong feeling that the union had not been consulted and that there could have been a breach of an agreement stating that there had to be consultation six months before new technology was introduced (Hlatshwayo, 2017b).

NUMSA's policy with regard to consultation about the introduction of new technology reads: "A company must give six months' notice of the introduction of new technology. This notice period must be before the decision to purchase the machinery has taken place" (NUMSA, 2012: 16). It appears that, in the case of VW, this policy was not enforced as the union was not apprised of the imminent introduction of this new technology. Probably, if NUMSA had tabled technological change as one of the primary bargaining issues at the plant, industry-level management at VW would have seen consultation before the introduction of robotics as a critical step in the company's innovation strategy.

When asked why managers tended not to consult trade unions and workers before new technology was introduced, Hangwayo replied:

An employer does not see the need to consult a union. His main concern is efficiency and what will benefit the company. These guys are in the business because they want to be profitable so they will innovate at every opportunity they run across (Hangwayo, Interview, 2017).

Unlike wages, managers of manufacturing plants view technology as their preserve, although technological change affects the nature of work, skills and numbers of jobs. This is then worsened by the fact that unions tend to put technological change on the back burner when it comes to collective bargaining, allowing managers to operate uncontested in the terrain of technology.

\section{Bargaining after the Introduction of New Technology}

To date, the unions have not engaged with employers before technology was introduced. It is always difficult for unions to ask a company to return machines and computers to their manufacturers when they have already been purchased. 
For example, NUMSA was concerned about the negative impact of new technology at a factory called Tiger Wheel and Tyre, which manufactured tyres. The union's statement indicated that NUMSA did not have a plan to engage proactively with technological changes at the plant in order to mitigate the effects of these changes on workers. Instead, the union complained and put media pressure on the company as part of what could be considered a rearguard strategy, since it entailed responding after the technology had been implemented. In 2004, NUMSA's media officer, Dumisa Ntuli (2004: 1), commented on the situation at Tiger Wheel and Tyre: "Since 1999 the company has retrenched over 400 workers as a result of the introduction of new technology".

Bafana Ndebele, who was responsible for campaigns and organising in NUMSA when he was interviewed, reflected on the bargaining that took place after the introduction of new machines:

We bargain for redeployment of workers to other plants. We would argue for them to be reskilled and we used the SETA [Sector Education and Training Authority]. There is a programme under MERSETA [Manufacturing, Engineering and Related Services SETA] which reskills workers who are about to be jobless: they are even skilled up to entrepreneurial level (Ndebele, Interview, 2011).

During the researcher's presentation and discussions with NUMSA officials, there was a general acceptance that the unions tended to bargain with employers after technology had already been introduced, and that negotiations with management focused on the redeployment of workers who had been replaced by machines. In some instances, these workers were made redundant and took severance packages (Hlatshwayo, 2017b).

\section{Capacity to Conduct Research on Automation}

Research has shown that trade unions with the capacity to conduct research on automation are able to mitigate the negative effects of technological changes on jobs and workers (Hlatshwayo, 2014). The COSATU research arm, the National Labour and Economic Development Institute (NALEDI), was established in 1993 to conduct research to improve the conditions of workers. Besides a contemporary project led by NUMSA and the Chemical, Energy, Paper, Printing, Wood and Allied Workers Union (CEPPWAWU), which focused on working conditions at German companies operating in South Africa (NALEDI, 2016: 1), there was no evidence of research which even came close to examining the role of technology in production, or union responses to it. Research programmes undertaken by NALEDI were concerned with labour market transformation, organisational renewal, changing the workplace, and social and economic justice. Currently, no attention at all is paid to challenges arising from automation (NALEDI, 2017).

Another labour research organisation is the Labour Research Service (LRS), which was founded in 1986. Its research has focused on wages and collective bargaining, working conditions, companies, campaigns, solidarity and HIV and AIDS. This organisation stated:

The LRS was a key input of the COSATU collective bargaining, organising and campaigns conference in March 2013. The programme has developed a set of sector resource packs for organising and bargaining in five vulnerable sectors of the economy (LRS, 2013: 8). 
Currently, the agendas of labour research organisations are largely driven by requests from trade unions, as most of the projects tend to be joint initiatives of unions and labour support organisations (LRS, 2013; NALEDI, 2017). As mentioned earlier, trade unions in South Africa emphasise bargaining related to wages, working conditions and sometimes organisational issues such as servicing of membership and the building of trade unions. This is reflected in the work done by these organisations.

In 2013 NUMSA launched its own Research and Policy Institute (NRPI), which "has assisted with improving our performance in Nedlac [National Economic Development and Labour Council], collective bargaining and research papers for engagement with government" (NUMSA, 2014: 9). NUMSA's (2013b) Special National Congress Declaration stated: “Technological changes, changes in production and restructuring of sectors and the impact of value chains necessitate new organisational strategies. Over time, we should move from organising along industrial/sectoral lines to organising along value chains". The union then proposed to "study value chains" and declared that:

... NUMSA's Research and Policy Institute will thoroughly investigate the value chain linkages relevant to our industries, including the possibility of having one collective bargaining council for the same value chain. The outcome of such research will be fed into constitutional structures (NUMSA, 2013a: 1).

Organising along the value chain means that NUMSA will organise workers mining iron, those who process iron ore and turn it into steel, those who process steel and turn it into products like nuts and bolts, those who sell the nuts and bolts and those who use bolts in car manufacturing. While NUMSA's declaration at the special congress mentioned the need to address technological changes as they impacted negatively on workers, the NRPI was a new institution and had not yet conducted research on automation. NUMSA officials also suggested that the research and development groups comprised of NUMSA members had to be re-established to help the union devise strategies for responding to technical changes at plant level (Hlatshwayo, 2017b).

\section{Workers' Education and Technological Changes}

The 2012 COSATU survey, which covered 3030 workers in thirty-seven urban districts, revealed that technology and work reorganisations are not topics for workers' education in COSATU trade unions. With regard to workers' education, the COSATU survey concludes:

By topic, the largest number of participants said they attended workshops or educational programmes on negotiations, labour law, employment equity and skills development. In part, the topics were determined by the availability of funding from the Department of Labour in particular. Around 10\% said they attended induction or shop stewards' training or political economy programmes, and a similar percentage attended programmes on gender or HIV/AIDS (COSATU, 2012: 27).

The topics covered by union education excluded much-needed education and training related to work reorganisation and automation. While focusing on topics like labour law and HIV and AIDS, the unions have concentrated on bread-and-butter issues pertaining to wages and working conditions. Input does not cover all the spheres of workers' lives, such as how they are affected by technology. 
The Development Institute for Training, Support and Education for Labour (Ditsela) was founded in 1996 by the trade union federations of South Africa to provide relevant education for union members. Funded largely by the state through the Department of Labour, Ditsela has provided structured courses, sometimes in collaboration with university academics, covering topics like Advanced Educator Training, Programme in Labour Law, Leading and Managing Trade Unions, Organiser Skills Development, Political Economy of Labour, and Women Leadership (Ditsela, 2014). Work reorganisation and technological change in production processes are not part of the programme, yet technological changes continue to affect workers and trade unions negatively.

When asked whether Ditsela had provided education on technological change, Makhi Ndabeni, a Ditsela staff member, replied: "Well, we have not gone to that extent. To be specific, I can say we have not run such workshops on technological changes" (Ndabeni, Interview, 2017). When asked why Ditsela had not done so, Ndabeni responded: "I can say that we are trying to acquaint ourselves with the technology that is out there" (Ndabeni, Interview, 2017).

According to Thobejane, in 2009 NUMSA organised a five-day retooling workshop for the organisation's 110 organisers. The delegates agreed that "there was an urgent need to retool its footsoldiers in how to respond to the current capitalist crisis that has resulted in massive job losses, shorttime and layoffs" (Thobejane, 2009: 1). While this was a critical development in dealing with changes in the workplace, it appeared that the "retooling" did not deepen engagement with workplace changes, nor with particular technological changes. Majafi was asked if organisers understood production issues and the challenges of technology, to which he replied: "No. I personally think that they don't have a clue. I will personally say they don't'" (Majafi, Interview, 2017).

Appolis noted the general decline in the quality of workers' education and debates and the lack of relevant discussion on work reorganisation. In the 1990s the Canadian intellectual Sam Gindin, who was associated with the Canadian Autoworkers union (CAW), was critical of co-determination, which was supported by the Australian labour activist Chris Lloyd. Both activists sought to influence the South African labour movements in the 1990s. According to Appolis:

I was not in much favour of the Australians, because they endorsed the entire question of flexibility with lifelong career workers for developers and individualisation of training, which I did not agree with much. But even if some of these ideas were problematic, it at least got unions to look more closely at work reorganisation and many things linked to the production process (Appolis, Interview, 2017).

A NUMSA shop steward in a steel plant concurred with Appolis and argued for a new form of training and education which would help to build capacity. John Sathali commented:

As shop stewards, we need training because the management has noticed that many of us lack education, so this disadvantages us during negotiations (Sathali, Interview, 2011).

\section{Union Structures and Production Issues}

Union structures are supposed to help the unions and their members advance the interests of workers from the workplace to the local, regional, national and even the global context. But it appears that union structures in South Africa do not help the unions or their members to even begin to respond 
adequately to technological and production changes.

Workers are at the coalface of technological change because they have to use machines and computers in the labour process. At two meetings, one convened by the NUMSA shop steward council of a steel company and the other with union officials at their head office, there was unanimous agreement that a strategy intended to respond to technological innovation has to be anchored by workers because they are directly affected by the changes.

The current situation is that workers see the machines being introduced and that makes it difficult for them to deal with the effects of technical changes as they are not informed prior to the introduction of the machinery, either by management or by their unions. General meetings of workers at plant level will have to take reports on technological changes and workers can also report on the impact of new machines on health and safety (Hlatshwayo, 2017a, 2017b).

John Sathali argued that union structures such as general meetings have been reactive in so far as technological changes are concerned:

We discuss the issues with shop stewards, management; we also touch on technology during our general meetings. But this happens after machines have been introduced (Sathali, Interview, 2011).

Shop stewards tend not to attend meetings of local structures. In 2014, COSATU resolved "to urge Affiliate organisers to attend meetings of Locals" (COSATU, 2014a: 1). The weakening of local union structures means that they are not able to unite workers or lead local campaigns to advance their interests, let alone deal with technological changes and production issues.

The unions hold national congresses which are supposed to provide strategic direction for union structures during the subsequent year. Besides electing union leaders, congresses assess the international, political, economic, and organisational contexts and help the unions to devise plans for dealing with challenges and advancing the interests of their members. From examining documentation of the COSATU Congress held in 2012 in Johannesburg, it was clear that production issues did not really feature, aside from a few mentions here and there. The congress was dominated by political discussions and concerns about divisions within the federation (COSATU, 2014b).

However, the NUMSA Congress Declaration of 2016 referred to automation and the Fourth Industrial Revolution, commenting that the latter is creating even more unemployment as machines and computer software efficiently perform tasks that workers used to do (NUMSA, 2016a: 2). However, the problem was that the congress did not provide for a comprehensive discussion on how to respond systematically to technological innovation.

\section{What have the Unions been Doing?}

Since the unions have not engaged with automation, what have they been doing? There are two key issues that seem to preoccupy union leadership and structures, namely "politics from above", which entails using political space to advance the individual interests of union leaders, and conventional union issues. Both these issues have been aggressively pursued by the unions at the expense of addressing production issues. Another factor that prevents the unions from developing adequate responses to technological change concerns the splits within the unions, which make the task of building the capacity to engage with technology even more difficult. 
First, COSATU is allied to the African National Congress (ANC), currently the ruling party in South Africa, and to the South African Communist Party (SACP). This alliance has facilitated a process of upward social mobility for many COSATU and affiliated union leaders, from local to national levels. For example, some Cabinet ministers and members of Parliament were trade unionists drawn from the ranks of COSATU (Masondo, 2012). Since the ANC has controlled the state and its companies, some former COSATU leaders have been employed in state agencies, earning substantial salaries and benefits. For example, in 2009 Randall Howard was part of the South African Transport and Allied Workers Union (SATAWU) and the COSATU leadership that supported Jacob Zuma, who later became the president of the ANC and of South Africa. Howard left the union to serve as a top government official (SATAWU, 2009; Department of Transport, 2016).

This focus on party politics takes place at the expense of dealing with technological changes and other production issues, and has led to complaints by workers. For example, a focus group which was part of the COSATU members' survey commented:

COSATU has influence but on issues that have nothing to do with workers ... like Polokwane and Mangaung, that's where you'll start to hear COSATU, but when it comes to worker issues on the ground and to influence government to change policies that affect workers, you find it asking (COSATU, 2014b: 1).

Due to political differences, NUMSA was expelled from COSATU in 2014. NUMSA had been involved in politics outside of the Alliance, by forming a united front of workers which was intended to forge links, through campaigns and struggle, to strengthen the economic and social positions of communities and workers. According to Whittles:

The National Union of Metalworkers of South Africa (NUMSA) is planning to form a political party to fight for the abolishment of capitalism and the nationalisation of white monopoly capital. It already has 170 potential foot-soldiers who will take up this cause at a national conference envisioned for next year (Whittles, 2016: 1).

"Crossing of the floor" - the movement of union leaders to management or government - has also been a localised phenomenon. Seeing a shop steward become a local government representative has affected the relationship between the ANC and COSATU (Mafa, Interview, 2011). Shop stewards also join management because of the broader politics of affirmative action and attempts to "deracialise" the workplace. For example, "It [NUMSA] does not want ex-NUMSA shop stewards promoted to human resources positions and then they become tokens because they are given no power to transform the workplace" (NUMSA, 2013: 1).

The unions tend to focus on bread-and-butter issues like wages, benefits and working conditions, including leave and disciplinary hearings. In 2016, members of CEPPWAWU who worked in oil refineries took part in a strike over wages. According to the reports, "Fifteen thousand of its [CEPPWAWU's] members have downed tools. demanding a $9 \%$ wage increase from the National Employment Association (NEA), which is only offering 6,5\%" (Ngcobo, 2016: 1). The NUMSA statement on collective bargaining in 2016 had wages as a key demand, as well as medical aid, insourcing, housing allowances and a ban on labour brokers (NUMSA, 2016b: 1). All these demands related to the redistribution of income from companies to NUMSA members; there were no demands 
relating to production and technological innovation.

Wages present a challenge, especially in South Africa, where working-class people's wages must cover basic needs like transport, housing, health, education and food. For instance, the state does not provide adequate health or education services, so workers are compelled to use privatised services. Wages are therefore a crucial element in the distribution of income and in securing access even to basic services. However, the unions also need to ensure that there is a balancing of the equation, in the sense that employees may grant a wage increase and later introduce new technology which displaces workers and offsets wage costs through retrenchments (Hlatshwayo, 2017b).

In February 2017, NUMSA's officials committed themselves to including technology and production as part of their agenda for the collective bargaining round. There was a realisation that although the employers wanted to use restructuring to deal with their problems of profitability, unions should demand production and technology plans so that they could formulate informed positions to save jobs (Hlatshwayo, 2017b).

The unions are currently divided and this makes it difficult for them to defend the rights and interests of their members, let alone intervene in matters of production. Mbhazima Shilowa, a former General Secretary of COSATU, writing about the divisions within the labour movement, pointed out: "It is now common knowledge that COSATU's central executive committee (CEC) took a decision to expel its biggest affiliate [NUMSA] from the federation for reasons that still have to be fully explained" (Shilowa, 2014: 1).

According to Letsoalo (2015), "R4-billion worth of investments - that appears to be at the centre of divisions and infighting in the Chemical, Energy, Paper, Printing, Wood and Allied Workers' Union". Corruption and struggles over control of the union's investment company meant that leadership of the union was unable to attend to the needs and aspirations of its members in the manufacturing sector.

The fact that NUMSA and Zwelinzima Vavi, another former General Secretary of COSATU who was dismissed by COSATU and other trade unions, launched a union federation which held its initial congress in April 2017, is further proof that workers' organisations are currently in disarray. According to Nicolson (2017), the new trade union federation will have no party-political affiliations, but will engage in politics to obtain benefits for workers and the poor. In addition, the new federation promises to organise precarious workers, who tend not to be organised. However, the new federation has not yet pronounced on production issues.

\section{What Explains the Rearguard Approach of the South African Manufacturing Unions?}

It has been established that the manufacturing unions adopted a rearguard approach which, among other things, entailed responding to technological change only after new technology had been introduced by management. They did not build research capacity to respond to technical changes, and wages and working conditions became a dominant mode of collective bargaining. Another factor was the dominance of "the politics of upwards social mobility".

The literature review has established that for trade unions to minimise the negative impact of technological changes, there should be legislation promoting participation. For example, Masondo (2010: i) concludes, "The German industrial relations system enables workers at the Kassel plant [in Germany] to influence and shape work restructuring through institutionalised participation”. Mashilo 
(2010) cautions that this model cannot just be replicated in South Africa because it emerged out of very specific German conditions, described earlier.

According to Siegel (2012), without strong worker participation, the institutionalised model is likely to lead to co-option of union leadership (cited in Hlatshwayo, 2013). Unlike the South African union context, the German system of industrial relations has an element of co-determination which provides for the representation of workers in works councils at the plant level and supervisory boards at company level (Bacon et al., 1996; Mashilo, 2010: 108).

In the cases of both Germany and Australia, research which is key to building internal capacity to respond to technical changes is critical, and the unions that conduct research on production view technology as a contested terrain (Mathews, 1989; Hlatshwayo, 2014). However, Mathews (1989) also indicates that management has to be committed to implementing some of the suggestions made by trade unions.

Based on the evidence from this research, it can be argued that none of these conditions existed, as there were no institutional arrangements, and the unions did not build their research capacity to respond to production issues. And what is really important in the South Africa case, trade unions did not formulate strategies for dealing with a management that was not willing to discuss production issues. The unions could have tabled production issues and technology during negotiations, but instead collective bargaining was dominated by wage negotiations. In addition, the unions were engaged in politics, which was basically about individual leaders gaining positions in government and private companies. Currently, this seems to be changing as unions like NUMSA are starting to adopt a more worker- and community-oriented type of politics. NUMSA has promised to table technology as one of the key bargaining issues in the coming round of collective bargaining.

\section{Militant Abstentionism?}

"Militant abstentionism" entails union adoption of measures opposed to participation in production issues (Webster et al., 2009: 26). More often than not, concepts like this are not grounded in the realities of the shop floor. Although unions are guided by certain ideologies, participation is often a tactical question (Bacon and Blyton, 2004), especially in the South Africa context. For example, in Highveld Steel and Iscor in the 1980s and 1990s, unions participated in factory-based work restructuring meetings organised by management. However, some sections of the workers saw that as a threat and their fears were confirmed when some of them lost their jobs (Hlatshwayo, 2013). This confirms Klerck's (1999) argument: "Since the employer constructs the terrain of employee representation, managerial strategies constrain the options and outcomes of participatory arrangements" (cited in Hlatshwayo, 2013: 193). In his examination of Nampak, a company that manufactures paper products in South Africa, Buhlungu (2010) narrated the result of union and management participation, which ended in disaster for workers. Buhlungu (2010: 87) pointed out sharply, "What was not said to the workers and the unions was that improved productivity and competitiveness would lead to job loss and labour market flexibility".

The South African Labour Relations Act (LRA) makes provision for workplace forums, which were inspired by German works councils. Trade unions, however, were concerned about the forums' potential for undermining unions on the shop floor, as representation in the forum is not union-based but driven by representation of workers across the board (Lehulere, 1995). Again, this speaks to the fact that unions and workers do not think that management wants to genuinely engage with them on 
production issues. Probably the intense competition among firms and the generalised loss of jobs militate against any real discussion on production issues in the South African context. It appears that the best form of response by the unions should be to combine production and wage issues in every round of bargaining. Strikes must not be just about wages, but also about production issues. This can only happen when unions demand access to production plans and devise research-based responses that seek to protect workers' interests. In this instance, the state can also be called upon to intervene practically in a manner that saves jobs, as jobs are part of the state's development agenda.

\section{Conclusion}

An organiser who participated in NUMSA's 2009 retooling workshop remarked, "We can stop acting like funeral undertakers in retrenchment consultations where our role is to assist in the removal of bodies of retrenchees from the workplace" (Thobjeane, 2009: 1). This highlighted the need for the unions to treat production and the restructuring of factories as a site of struggle. However, instead of saving the working lives of their members, the unions continue to act as their undertakers. Union members are at the coalface of automation as capital seeks to expand and improve its profit margins globally, using technology to increase the production pace and improve the quality of products. In South Africa, according to the findings of this research, the manufacturing unions will have to change gear and adopt an organisational perspective that contests managerial control over technology. This will not be easy as these unions have been weakened by retrenchments, divisions and poor servicing of their membership.

\section{REFERENCES}

Babbie, E., J. Mouton, P. Voster and B. Prozesky (2001) The Practice of Social Research. South African edition. Oxford and New York: Oxford University Press.

Bacon, N. and P. Blyton (2004) Trade Union Responses to Workplace Restructuring: Exploring Union Orientations and Actions. Work, Employment and Society, 184:749-777.

Bacon, N., P. Blyton and J. Morris (1996) Among the Ashes: Trade Union Strategies in the UK and German Steel Industries. British Journal of Industrial Relations, 4(1): 25-50.

Bamber, G. (1988) Technological Change and Trade Unions. In New Technology and Industrial Relations, edited by R. Hyman and W. Streeck. Oxford: Basil Blackwell.

Bonin, D. (2013) Global Integration, New Technologies and the Work of South African Textile Designers. South African Review of Sociology, 44(2): 112-130.

Boyce, C. and P. Neale (2006) Conducting In-depth Interviews: A Guide for Designing and Conducting Indepth Interviews for Evaluation Input. Available online at http://dmeforpeace.org/sites/default/files/Boyce_In\%20Depth\%20Interviews.pdf [accessed 12 March 2017].

Braun, V. and V. Clarke (2006) Using Thematic Analysis in Psychology. Qualitative Research in Psychology, 3(2): 77 101. Available online at http://eprints.uwe.ac.uk/11735/2/thematic_analysis_revised... [accessed: 12 March 2017].

Buhlungu, S. (2010) A Paradox of Victory: COS ATU and the Democratic Transformation in South Africa. Durban: University of KwaZulu-Natal Press. 
Congress of South African Trade Unions (COSATU) (2012) Findings of the COSATU Workers' Survey, 2012. Johannesburg: COSATU.

Congress of South African Trade Unions (COSATU) ( 2014a) Organisational Resolutions adopted at 11th COSATU Congress. 4 June 2014. Available online at http://www.cosatu.org.za/ show.php?ID=9061\#sthash.o4nBi9Fu.dpuf [accessed 12 March 2017].

Congress of South African Trade Unions (COSATU) (2014b) Secretariat Report to the 11th COSATU National Congress. Available online at http://www.cosatu.org.za/show.php?ID=6535 \#sthash.PEifvSpW.dpuf [accessed 12 March 2017].

Danford, A., M. Richardson, P. Steward, S. Tailby and M. Upchurch (2004) High-performance Work Systems and Workplace Partnership: A Case Study of Aerospace Workers. New Tcchnology, Work \& Employment, 19(1): 14-29.

Department of Transport (2016) Charter Council Background. Available online at http://www.transport.gov.za/IntegratedPlanning/BlackEconomicEmpowerment/TransportSectorBBB EECharterCouncil.aspx [accessed 12 March 2017].

Development Institute for Training, Support and Education for Labour (Ditsela) (2014) 2014 National Programme. Available online at http://www.ditsela.org.za/Articles/2014-National-Programme [accessed 12 March 2017].

Dribbusch, H. (2013) Union Membership Holds Up Well. Available online at www.eurofound.europa.eu/eiro/2013/04/articles/de1304019i.htm [accessed 3 February 2017].

Hlatshwayo, M. (2013) A Sociological Analysis of Trade Union Responses to Technological Changes at the ArcelorMittal Vanderbijlpark Plant, 1989-2011. Unpublished doctoral thesis, Faculty of Humanities, University of Johannesburg.

Hlatshwayo, M. (2014) NUMSA and Solidarity's Responses to Technological Changes at the ArcelorMittal Vanderbijlpark Plant: Unions Caught on the Back Foot. Global Labour Journal, 5(3): 283-305.

Hlatshwayo, M. (2017a) Minutes of meeting held on 18 February 2017, Vanderbijlpark.

Hlatshwayo, M. (2017b) Minutes of meeting held on 8 March 2017, Johannesburg. IndustriALL (2016) Action Plan of IndustriALL Global Union. Available online at http:/ /www.industriall-union.org/about-us/actionplan-of-industriall-global-union [accessed 12 March 2017].

Jarvis, D., S. Isaacs, J. Nicholson and G. Phillips (1999) Making Sense of Workplace Restructuring. Durban: Trade Union Research Project.

Jarvis, D., S. Isaacs, J. Nicholson and G. Phillips (1999) Making Sense of Workplace Restructuring. Durban: Trade Union Research Project.

Klerck, G. (1999) Adversarial Participation and Antagonistic Cooperation? Workplace Forums, Employee Participation and Lean Production. Transformation, 40:1-35.

Labour Research Service (LRS) (2013) Annual Report: 2013. Available online at http://www.lrs.org.za/docs/LRS\%20Annual\%20Report\%202013.pdf battle [accessed 12 March 2017].

Lehulere, O. (1995) Workplace Forums: Co-determination and Workers' Struggle. South African Labour Bulletin, 19(2): 41-46.

Letsoalo, M. (2015) Union Billions at Heart of Battle. Available online at https://mg.co.za/article/2015-05-21union-billions-at-heart-of-battle [accessed 12 March 2017].

Lukman, S. (2012) The Nigeria Labour Congress and the Challenges Ahead. Ibadan: Gamji. Available online at http://www.gamji.com/article6000/NEWS6826.htm [accessed 15 October 2012].

Maree, J. (1984) Trade Unions, Redundancies and New Technology Agreements. Cape Town: Southern Africa Labour and Development Research Unit (SALDRU). 
Markovits, A. (2016) The Politics of West German Trade Unions: Strategies of Class and Interest Representation in Growth and Crisis. New York: Routledge.

Mashilo, A.M. (2010) Changes in Work and Production Organisation in the Automotive Industry Value Chain: An Evaluation of the Responses by Labour in South Africa. Unpublished Masters Research Report, University of the Witwatersrand, Johannesburg.

Masondo, T. (2010) Worker Participation in Workplace Restructuring in the Automotive Industry: A Comparative Study of German and South African Volkswagen Plants 1970-2009. Unpublished Masters Research Report, University of the Witwatersrand, Johannesburg.

Masondo, T. (2012) The Sociology of Upward Social Mobility Among COSATU Shop Stewards. In COSATU's Contested Legacy, edited by S. Buhlungu and M. Tshoaedi. Cape Town: Human Sciences Research Council.

Mathews, J. (1989) Tools of Change: New Technology and the Democratisation of Work. Sydney: Pluto Press.

McLoughlin, I. and J. Clark (1988) Technological Change at Work. Milton Keynes: Open University Press.

Naki, E. (2016) Minister Patel Unveils Plan to "boost" Manufacturing at Numsa Congress. The Citizen, 14 November 2016. Available online at http://citizen.co.za/news/news-national/1375081/minister-patelunveils-plans-to-boost-manufacturing-at-numsa-congress/ [accessed 12 March 2017].

National Labour and Economic Development Institute (NALEDI) (2016) Changing the Workplace. Available online at http://www.naledi.org.za/changing-the-workplace [accessed 12 May 2017].

National Labour and Economic Development Institute (NALEDI) (2017). Programmes. Available online at http:/ /www.naledi.org.za / [accessed 12 March 2017).

National Union of Metalworkers of South Africa (NUMSA) (2012) NUMS A Policy Resolutions, Edited Version. Available online at http://www.numsa.org.za/wp-content/uploads/2013/10/Section-2-OCCB-EditedVersion-9-consolidated-changes.htm [accessed 12 May 2017].

National Union of Metalworkers of South Africa (NUMSA) (2013a) NUMSA's Principles. Available online at http://www.numsa.org.za/numsas-policies-and-principles/ [accessed 12 March 2017].

National Union of Metalworkers of South Africa (NUMSA) (2013b) Special National Congress Declaration, 17-20 December 2013. Available online at https://www.numsa.org.za/wp-content/uploads/2013/12/SNCDeclaration-final-copy.pdf [accessed 12 May 2017].

National Union of Metalworkers of South Africa (NUMSA) (2014) Open Numsa Response to a Spurious Attack on NUMSA Leaders and Structures coming from a Group of 36 Former and Current NUMSA Members in a Benoni Meeting held on 25 May 2014. 20 June 2014. Johannesburg: NUMSA.

National Union of Metalworkers of South Africa (NUMSA) (2016a) Declaration: NUMSA 10th National Congress, Cape Town. 12-15 December 2016.

National Union of Metalworkers of South Africa (NUMSA) (2016b) NUMSA Statement on Progress in the 2016 Bargaining Round. Available online at http://www.numsa.org.za/article/numsa-statement-progress2016-bargaining-round [accessed 12 March 2017].

Ngcobo, Z. (2016) Ceppwawu Members Down Tools for Higher Wages. EWN, 28 July 2016. Available online at http://ewn.co.za/2016/07/28 /Ceppwawu members down tools for higher wages [accessed 12 March 2017].

Nicolson, G. (2017) Vavi \& Co: New Federation Saftu Launches, Now the Work Begins. Daily Maverick, 24 April 2017. Available online at https://www.dailymaverick.co.za/article/2017-04-24-vavi-co-newfederation-saftu-launches-now-the-work-begins/\#.WRshOtwlHIU [accessed 12 May 2017].

Ntuli, D. (2004) Numsa Press Release - Tiger Wheel to Retrench 700 Workers in order to Introduce New Technology, 24 November 2004, Johannesburg. Available online at http://www.numsa.org.za/article/tiger-wheels-to-retrench-700-workers-in-order-to-introduce-new- 
technology [accessed 12 March 2017].

Palys, T. (2008) Purposive Sampling. In The Sage Encyclopedia of Qualitative Research Methods, edited by L.M. Given. Los Angeles: Sage.

Saiyadain, M.S. (2001) Modernization of Mind at Tata Steel. Indian Journal of Industrial Relations, 36(3): 363-375.

Sandberg, A. (1985) Socio-technical Design, Trade Union Strategies and Action Research. Swedish Centre for Working Life. Available online at http://ifipwg82.org/sites/ifipwg82.org/files/Sandberg.pdf [accessed 12 February 2017].

Shilowa, M. (2014) Cosatu: A Giant Falls. Available online at http:/ /www.sahistory.org.za/archive/cosatu-giantfalls-mbhazima-shilowa-city-press-18-november-2014 [accessed 12 March 2017].

South African Transport and Allied Workers Union (SATAWU) (2009) Statement on the Election of the Acting General Secretary of SATAWU. Available online at http://www.cosatu.org.za/show.php?ID=2651\#sthash.CoIPfxhm.dpuf [accessed 12 March 2017].

Staff Writer (2016) 67\% of Jobs in South Africa can be Done by Robots. MyBroadband. Available online at https:// mybroadband.co.za/news/business/158867-67-of-jobs-in-south-africa-can-be-done-byrobots.htm [accessed 12 March 2017].

Streeck, W. and K. Thelen (2005) Introduction: Institutional Change in Advanced Political Economies. In Beyond Continuity: Institutional Change in Advanced Political Economies, edited by W. Streeck and K Thelen. Oxford: Oxford University Press.

Taylor, S.J., R. Bogdan and M. DeVault (2015) Introduction to Qualitative Research Methods: A Guidebook and Resource. Hoboken, N.J.: John Wiley \& Sons.

Thelen, K. (1991) Union of Parts: Labor Politics in Post-war Germany. New York: Cornell University Press.

Thobejane, P. (2009) NUMSA Organisers Ready to Tackle the Job Crisis. Available online at http://www.numsa.org.za/article/numsa-organisers-ready-to-tackle-the-jobs-crisis [accessed 12 March 2017].

Venter, I. (2016) Inside VWSA's Revamped Bodyshop. Engineering News, 13 October 2016. Available online at http://www.engineeringnews.co.za/article/vwsa-installs-320-robots-ahead-of-new-polo-production2016-10-13/rep_id:4136 [accessed 12 March 2017].

Von Holdt, K. (2003) Transition from Below: Forging Trade Unionism and Workplace Change in South Africa. Pietermaritzburg: University of Natal Press.

Webster, E., A. Mashilo, T. Masondo and C. Bischoff (2009) Changes in Production Systems and Work Methods. Johannesburg: National Union of Metalworkers of South Africa, Frederick Ebert Foundation, Sociology of Work Programme and Development Institute for Trade Union Support and Education for Labour.

Whittles, G. (2016) Numsa Sets to Work on a Socialist Party. Available online at https://mg.co.za/article/201612-15-00-numsa-sets-to-work-on-a-socialist-party [accessed 12 March 2017].

\section{Interviews}

Appolis, J. (2017) Personal interview. 6 January.

Hangwayo, M. (pseudonym). Quality Manager, Boksburg. Personal interview. 29 January 2017.

Kudwana, M. (pseudonym). Steelworker, Vanderbijlpark. Personal interview. 7 January 2017.

Mafa, P. (pseudonym). NUMSA official. Personal interview. February 2011.

Majafi, M. (pseudonym). NUMSA shop steward, Vanderbijlpark. Personal Interview. January 2017. 
Ndabeni, M. Librarian and educator. Personal interview. 13 December 2016.

Ndebele, B. Former NUMSA official, Johannesburg. Personal interview. 26 January 2011.

Nyathi, J. (pseudonym). Quality consultant, Boksburg. Personal interview. 29 January 2017.

Rees, R. Researcher. Personal interview. 23 January 2017.

Sathali, J. (pseudonym). Steelworker, Vanderbijlpark. Personal Interview 20 March 2011.

\section{BIOGRAPHICAL NOTE}

MONDLi HLATHSWAYO is a senior researcher and lecturer in the Centre for Education Rights and Transformation (CERT) at the University of Johannesburg. [Email: mshlatshwayo@uj.ac.za] 